\title{
FUNDAMENTAL ANALYSIS - POSSIBLITY OF APPLICATION ON THE REAL ESTATE MARKET
}

\author{
Marta Figurska, M.Sc. \\ Faculty of Geodesy, Geospatial and Civil Engineering \\ University of Warmia and Mazury in Olsztyn \\ e-mail: marta.figurska@uwm.edu.pl \\ Radoslaw Wisniewski, assoc. prof., Ph.D. \\ Faculty of Geodesy, Geospatial and Civil Engineering \\ University of Warmia and Mazury in Olsztyn \\ e-mail:danrad@uwm.edu.pl
}

\begin{abstract}
The most common method supporting investing on the capital market or making decisions on the real estate market is technical analysis. This article, however, focuses on the less popular fundamental analysis, the importance of which is increasing on internationals markets, especially fully-developed ones.

Fundamental analysis is used for long-term predictions of values of future phenomena, based on historical data and any factors likely to affect the level of supply and demand. The final result of its use is an appraisal the true value of the subject of valuation, or so-called fundamental (intrinsic) value.

Using this method to analyze, diagnose and forecast economic phenomena, as well as become familiar with the market in terms of its fundamentals, positively influences the process of taking investment measures and leads to a better understanding of the real estate market.

The aim of the following study is to describe the possibility of applying fundamental analysis on the real estate market, based on the principles existing on capital markets. This article serves as an introduction to the subject-matter as well as the beginning of series of publications dedicated to different aspects of conducting fundamental analysis in the context of the real estate market.
\end{abstract}

Key words: fundamental analysis, intrinsic value, fundamental factors, real estate market.

JEL Classification: B40, D46, R00, R53.

Citation: Figurska M., Wisniewski R., 2016, Fundamental Analysis - Possiblity of Application on the Real Estate Market, Real Estate Management and Valuation, vol. 24, no. 4, pp. 35-46.

DOI: $10.1515 /$ remav-2016-0028

\section{Introduction}

Since the dawn of time, human beings have been trying to find their way in the surrounding world. Along with the birth of the economy, the understanding of some aspects of reality was considerably simplified thanks to the awareness of the value of its various elements, enabling their hierarchisation.

Comparing objects on the basis of their value makes sense only when this valuation is carried out in an objectified way. Appraisers aim at such a state by adjusting their workshop to certain standards in the form of frameworks and restrictions defined in advance. Nevertheless, the obtained types of real estate value (i.e. market or replacement value) are always - to a certain extent - tainted with subjectivism. These observations served as the foundation for expanding the scope of the research to look into new solutions. 
Fundamental analysis, which has been functioning on capital markets since the $20^{\text {th }}$ century, may be an answer to a such determined problem. It results are not only in an economic forecast in the form of intrinsic value, presenting the true value of the item of valuation, but also leads to a better understanding of the processes occurring on the real estate market.

This paper will present an attempt at answering the following question: is it possible to transfer fundamental analysis from the capital market to the real estate market?

\section{Literature Review - Fundamental Analysis on Capital Markets and the Real Estate Market}

Nowadays, the most common method supporting investing on the capital market or making decisions on the real estate market is technical analysis. In addition to predicting future prices, its aim is to indicate precise moments in the future when it will be worth to sell or buy. These actions are carried out every time with the assumption of repeatability, possible to observe in charts of schemes, according to which prices are subject to change; an assuption that prices vary under repetitively observable diagrammatic scenarios.

The article focuses, however, on fundamental analysis, which is gaining more and more importance on internationals markets, especially those fully-developed, balanced and of many-year traditions, where technical analysis is begeinning to play a secondary role (ŁUNIEWSKA, TARCZYŃSKI 2006, p. 71).

David DODD and Benjamin GRAHAM, who were the first to describe the rules of this method of forecasting in their book Security Analysis, published in 1934, are considered to be the creators of fundamental analysis (NAZAROWA 2014, p. 290). They are currently widely believed to be the most influential investment philosophers of all-time, who forever changed the theory and practice of this activity with their publication regarded as a kind of "bible of investing" (GRAHAM et al. 2009, p.v).

Over the last 80 years, fundamental analysis has developed a number of methods of determining intrinsic value, that is the true value which the price of a particular venture is heading towards over a longer period of time. This analysis is a constantly evolving science, as evidenced by emergence of newer and newer valuation methods (BOROWSKI 2014, p. 10).

Among the most famous advocates of fundamental analysis, in addition to GRAHAM and DODD, we should mention investors such as Warren E. BUFFETT (see: GRAHAM et al. 2009, 2003), Peter LYNCH (see: LYNCH, ROTHCHILD 2000, 2012; LYNCH 2012) and Philip A. FISHER (see: FISHER 2015). BUFFET alone with his policy of investment decision-making became an inspiration for a large number of authors (see: CALANDRO 2009; CunNINGHAM 2001, 2003; HAGSTROM 2009; HAGSTROM et al. 2014).

Nevertheless, fundamental analysis is not very popular among market analysts. SURDEL (2004, p. 95) remarks that, especially amidst beginner market participants, technical analysis is better acknowledged, mainly because of the ease of its use and high level of automatization, which does not require vast economic knowledge.

While technical analysis gives a framework for studying investors' behaviors, fundamental analysis provides a mechanism for evaluating the financial condition of a venture (HAFEZI et al. 2015, p. 197). The essential difference between these two methods is summarized by MURPHY (1999, p. 5): "The fundamentalist studies the cause of market movement, while the technician studies the effect."

Fundamental analysis is used for long-term predictions of values of future phenomena based on historical data and a set of other factors which may affect, in any way, the level of demand and supply (KRZYWDA 2010, p. 55). Both measurable and non-measurable features (quantitative and qualitative factors) are included. According to DAMODARAN (2012, p.6), the main purpose and final result of its application is determining the the object's true value, the so-called fundamental (intrinsic) value.

This analysis is based on the assumption that it is possible to isolate a certain group of factors having a quantifiable influence on the intrinsic value, and to determine the scale of their impact on the formation of future market prices. This assumption is in opposition to technical analysis, which adopts an unlimited number of factors influencing the price level on the market, both fundamental and behavioural, as well as rational and irrational. That is why technical analysis is limited to assessing changes in currency exchange rates (PANFIL, SZABLEWSKI 2011, p. 108).

In the case of the stock market, fundamental analysis is based on studying the economic bases of companies (BOROWSKI 2014, p.9), using financial statements and current information about the company to determine future values of its shares (HONG, WU 2016, p. 62; EDIRISINGHE, ZHANG 2008, p. 842; POMYKALSKA, POMYKALSKI 2008, p. 281). In this analysis, investment profitability 
is determined on the basis of the financial condition of the company, its stability on the market and development perspectives (ŁUNIEWSKA 2008, p. 97).

The foregoing premises unambiguously indicate that the scheme of conducting such a complex analysis is complicated, which is connected with the necessity of possessing appropriate qualifications and considerable prolongation of investment decision-making time.

In accordance with literature (Hu et al. 2015, p. 537; BOROWSKI 2014, p. 30; PANFIL, SZABLEWSKI 2013, p. 112; JAJUGA, JAJUGA 2012, p. 149; KRZYWDA 2010, p. 55; ŁUNIEWSKA 2008, p. 98), fundamental analyses are carried out in the following stages:

1. macroeconomic analysis of the environment,

2. sector (branch) analysis,

3. condition analysis,

4. financial analysis,

5. intrinsic value appraisal.

\subsection{Macroeconomic Analysis of the Environment}

Macroeconomic analysis of the environment consists of the observation of phenomena occurring in the economy, as well as its condition and fluctuations, to formulate forecasts regarding the rate of its development and to estimate the attractiveness of investing in a particular country (DĘBSKI 2012, p. 215). In this case, global assessment of the economic and political situation, which can have a significant impact on domestic markets, should not be omitted (JAJUGA, JAJUGA 2012, p. 149).

This phase includes an analysis of typical macroeconomic indices (GDP growth rate, inflation, unemployment rate, interest rates), but also of non-measurable elements such as political stability, tax policy, rules of employment, scientific potential, infrastructure, the demographic situation or social-cultural habits.

The better the assessment results of a particular country's economic situation, the greater the investment attractiveness of its capital market. This is connected with a higher ability to generate income and to fulfil commitments undertaken by the companies (PANFIL, SZABLEWSKI 2013, p. 112).

\subsection{Sector (Branch) Analysis}

Sector (branch) analysis means an examination of a group of similar sectors in terms of qualitative factors typical for them, among which BOROWSKI (2014, p. 32) lists:

- historical and expected returns on investments,

- level of risk associated with investments,

- sensitivity to the economic situation,

- position on the map of the life-cycle of the industry (start, growth acceleration, maturity and decline),

- scale, directions and pace of changes along with their causes,

- recipients' response to changes of prices and quality of products,

- level of market saturation,

- price elasticity of demand.

To the above set, DęBSKI (2012, p. 216) adds statistical data and indices regarding, in particular: "sales, profit, paid dividend, salaries, capital structure, investment profitability, but also applied technology, innovations, accessibility to raw materials, law."

The main aim of this analysis is to determine the magnitude of the influence of the environment and its relevant changes on the economic results and development opportunities of a specific business venture (PANFIL, SZABLEWSKI 2013, p. 113).

\subsection{Situation Analysis}

Situation analysis results in the evaluation of a business venture in comparison with the entire business sector, determining the level of profitability (BOROWSKI 2014, p. 35), its competitive position, and the company's market share and prospects for its possible increase or decrease in the future (PANFIL, SZABLEWSKI 2013, p. 114).

Situation analysis is executed mainly on the basis of non-financial aspects (so-called soft factors), such as: strategy and development prospects, barriers to entering the market, difficulty with acquiring new distribution channels, the number of suppliers and consumers, product specification and the 
possibility of its substitutes appearing, quality of management and employees, intellectual capital, applied technology and innovation capacity, loyalty of consumers and social reputation (BOROWSKI 2014, p. 35; PANFIL, SZABLEWSKI 2013, p. 114; OSTROWSKA 2007, p. 120; JAJUGA, JAJUGA 2012, p. 150).

Under condition analysis, SWOT analysis is commonly used, examining the strengths and weaknesses of a venture as well as opportunities and threats resulting from the environment it exists in, dividing them into internal and external factors. Unequivocal estimation of the level of impact such information has on intrinsic value is not possible, however, as no accurate algorithms for the procedure have been developed as of yet. Determining the importance of these factors, even as an approximation, can contribute to objectivizing processes of intrinsic value appraisal.

\subsection{Financial Analysis}

Financial analysis, on the other hand, is based mainly on quantitative data and evaluates the overall performance of a business (its economic and financial condition) on the basis of data from published reports (prospectus, periodical reports, balance sheets, profit and loss account, cash flow statement, statement of changes in equity, minutes of management board meetings and control protocols) and factors influencing these results. As PANFIL, SZABLEWSKI (2013, p. 133) notice, apart from the abovementioned sources, at this stage, information obtained during interviews and external materials referring to the company's environment are used as well.

This analysis takes into account not only the circumstances influencing a company's situation at a given moment but also their trends over time (RITCHIE 1997, p. 19). It most frequently involves two stages:

1. preliminary (balance sheet) analysis - examining the structure by the analysis of elements of financial statements (PANFIL, SZABLEWSKI 2013, p. 115):

1) vertical (static) - the structure of assets (percentage of particular assets) and sources of their financing at the analyzed moment;

2) horizontal (dynamic) - the direction and dynamics of changes of particular assets in comparison with their previous values;

2. ratio analysis - calculation and interpretation of economic and financial indices (ratios): liquidity, leverage, activity (productivity), profitability, market value - on the basis of information included in reporting documents to synthetically characterize a selected company and its economic activity.

According to BOROWSKI (2014, p.38), assigning ratios to particular groups is accomplished on the basis of relations occurring between them. Becoming acquainted with these relations greatly facilitates the carrying of analyses and the further valuation of a venture (e.g. during company valuation using methods of multipliers).

Ratio analysis consists of (http:// bossa.pl/edukacja/AF/, available at 21.07.2015):

1. trend analysis - comparison of the same ratios over a couple of periods of time;

2. comparative analysis - comparison of ratios calculated for a given company with ratios calculated in the same way for similar companies or averages for the sector (industry) in the same period of time.

\subsection{Intrinsic Value Appraisal}

The final result and the main purpose of fundamental analysis is the appraisal of a chosen asset's intrinsic value. The term "intrinsic value" was used for the first time in 1848 by William ARMSTRONG in a brochure Stock-Jobbing in Wall Street (ARNOLD 2010, pp. 88). Putting it more simply, value is either a function of a venture's assets or a derivative of generated income in the form of cash flows, profits or dividends (PANFIL, SZABLEWSKI 2013, pp. 119). In specialist literature, it is defined as presented in Table 1.

Table 1

Definitions of intrinsic value of a company (a share)

\begin{tabular}{cl}
\hline Source & \multicolumn{1}{c}{ Definition } \\
\hline ARNOLD 2010, p. 88 & $\begin{array}{l}\text { "[intrinsic value is] a price justified by the facts. These facts } \\
\text { include the assets, earnings, dividend and definite prospects } \\
(\ldots) ; \text { determined by its "earning power" }\end{array}$ \\
\hline
\end{tabular}




\begin{tabular}{|c|c|}
\hline ARNOLD 2010, p. 530 & $\begin{array}{l}\text { "Intrinsic value (company) - the discounted value of the cash } \\
\text { that can be taken out of a business during its remaining life. } \\
\text { Intrinsic value (options) - the payoff that would be received if } \\
\text { the underlying is at its current level when the option expires." }\end{array}$ \\
\hline CUNNINGHAM 2001, p. xi & $\begin{array}{l}\text { "[intrinsic value] It is the sum of all future cash flows the share } \\
\text { or the index will generate in the future, discounted to present } \\
\text { value." }\end{array}$ \\
\hline CUNNINGHAM 2013, p. 224 & $\begin{array}{l}\text { " [intrinsic value] is the discounted value of the cash that can be } \\
\text { taken out of a business during its remaining life" }\end{array}$ \\
\hline DĘBSKI 2012, p. 219 & $\begin{array}{l}\text { "Intrinsic value is understood as a tendency, towards which } \\
\text { share price aims in a longer period." }\end{array}$ \\
\hline DĘBSKI 2012, p. 219 & $\begin{array}{l}\text { "value of shares can be calculated as a sum of [financial] } \\
\text { surpluses earned by the company during a particular period } \\
(\ldots) \text {, after having them reduced to a present value." }\end{array}$ \\
\hline DĘBSKI 2012, p. 220 & $\begin{array}{l}\text { "value of a share can be treated as limits of its price } \\
\text { in transactions concluded on stock" }\end{array}$ \\
\hline DĘBSKI 2012, p. 221 & $\begin{array}{l}\text { "[intrinsic value of a share is] a sum of discounted future profits, } \\
\text { meaning present values of projected incomes (..) during } \\
\text { particular periods" }\end{array}$ \\
\hline DĘBSKI 2012, p. 222 & $\begin{array}{l}\text { "intrinsic value of a share }(\ldots) \text { is equal to a sum of discounted } \\
\text { dividends which will be paid in the future because of keeping a } \\
\text { particular share" }\end{array}$ \\
\hline FUNG, et al. 2010, p. 829 & $\begin{array}{l}\text { "Fundamental value of a firm (...) is typically defined as the } \\
\text { present value of the firm's expected future dividends based on } \\
\text { all currently available information." }\end{array}$ \\
\hline
\end{tabular}

KRZYWDA 2010, p. 56

"Intrinsic value is equivalent to the profit, that is a difference between income and cost."

LAVIN 2001, p. 99

"Fundamental value is usually defined to be the present value of the future cash flows associated with a particular asset."

ŁUNIEWSKA 2008, p. 11

"Intrinsic value is a true (objective) price of an asset (share) uninfluenced by demand and supply on the market."

PANFIL, SZABLEWSKI 2011, p. 27

"as (...) an [intrinsic] value of a company we understand its ability to generate free cash flows in the future."

\begin{tabular}{ll}
\hline YAN et al. 2014, p. 1275 & $\begin{array}{l}\text { "Fundamental value reflects the intrinsic value } \\
\text { (and is sometimes called this) of the asset itself. It is ordinarily } \\
\text { calculated by summing the future incomes generated } \\
\text { by the asset, which are discounted to the present." }\end{array}$ \\
\hline YEH, et al. 2008, p. $143 \quad \begin{array}{l}\text { "The intrinsic value is a valuation measure based on a firm's } \\
\text { fundamental performance (such as sales, earnings, and book } \\
\text { values)." }\end{array}$ \\
\hline
\end{tabular}

Source: own study.

Because of the equivocal perception and different categories of value (book, income, market, replacement, liquidation value), as well as the multitude of factors influencing it, numerous valuation methods have been developed: asset- and income-based, comparative, and mixed; different 
approaches, however, guarantee obtaining divergent results (PANFIL, SZABLEWSKI 2011, p. 125; DĘBSKI 2012, p. 219).

The above differences and market imperfection influence the fact that, in the community of analysts and investors, it is assumed that prices hardly ever reflect true value; they rather fluctuate around some hypothetical value, which is the fundamental value (GAO, LI 2011, p. 376). Still, the sources of this deviation remain contentious (HONG, WU 2016, p. 62). As MALINOWSKA (2012, p. 31) and GRAY et al. (2003, p. 84) remark, fundamental analysis relies on the assumption that, in longer periods of time, the market will aim, through self-regulation, towards reaching equilibrium, hence market price and intrinsic value will gradually converge; or the longer the time over which the venture is exercisable on the market, the higher the probability of its price reaching this value (ARNOLD 2010, p. 205).

The long-term approach to appraisal will also allow to eliminate random factors from the process of price formation. Economic factors will then be of crucial importance (DĘBSKI 2012, p. 215). If a forecast of future price movements is not based on fundamentals, it will have no predictive power (BONENKAMP et al. 2011, p. 842).

Intrinsic value is subject to constant changes as a result of accompanying changes in the economy and the company's strategy; nevertheless, it is objective, contrary to capital market appraisal, which also includes subjective factors and is of a speculative nature (PANFIL, SZABLEWSKI 2011, p. 27). "Intrinsic value can never be precisely calculated; it will always be an estimate. We are dealing with future events about which it is impossible to be certain" (ARNOLD 2010, p. 205).

Finally, after estimating the intrinsic value, under fundamental analysis, its comparison with the price of a particular asset ensues. The result of such a comparison is giving one of the following recommendations (BOROWSKI 2014, p. 39; GRAY et al. 2003, p. 87; MURPHY 1999, p. 5):

- "buy" - advisable in the case of the intrinsic value being higher than market price (undervaluation),

- "sell" - if intrinsic value is lower than market price (overvaluation),

- "hold" - if the obtained difference is insignificant and shares are very promising for the future and have strong fundamentals.

\section{Data and Methods}

Taking into account the interdisciplinary character of fundamental analysis and the fact that it has not yet been the subject of more thorough studies on the real estate market, especially in Poland, the following article will represent only an introduction to the subject-matter related to it, and a presentation of preliminary guidelines for further research.

The main purpose of the study will be to determine fundamental factors for the real estate market in synergistic processes of price variations, basws on a thesis assuming the existence of a group of factors regarded as fundamental.

As DĘBSKI (2012, p. 216) remarks, in order to receive correct results of a conducted fundamental analysis and to consider them reliable, 3-to-5-year time series, additionally covering comparable periods, should be used. In the case of data on Polish companies, this requirement is rather difficult to fulfil, however the authors of the article presume that collecting proper information about real estate should be less problematic.

Therefore, the study conducted by the authors of the article will apply to a 10-year time horizon, initially covering a local real estate market (Olsztyn), to later expand to the regional market (WarmiaMasuria Province).

\section{Empirical Results}

\subsection{Basic Research Premises}

Research related to fundamental analysis on the real estate market would be carried out in three areas (see: Fig. 1.):

- informative: analysis of scientific data sources (databases, price and value register, Central Statistical Office of Poland, National Bank of Poland, Geographic Information System, others);

- substantive: methodology of real estate sector fundamental analysis (action theory);

- instrumental: methodology of real estate sector fundamental analysis (executive practice).

The subject-matter of fundamental analysis will be examined on three main levels: 
1. analysis of real estate market system fundamentals (basics) resulting in the identification and systematization of fundamental factors connected with the closer and further environment of real estate,

2. actual fundamental analysis of a selected market/sector/group/real estate, providing suitable tools for the final phase, which is:

3. appraisal of the fundamental value of the real estate.

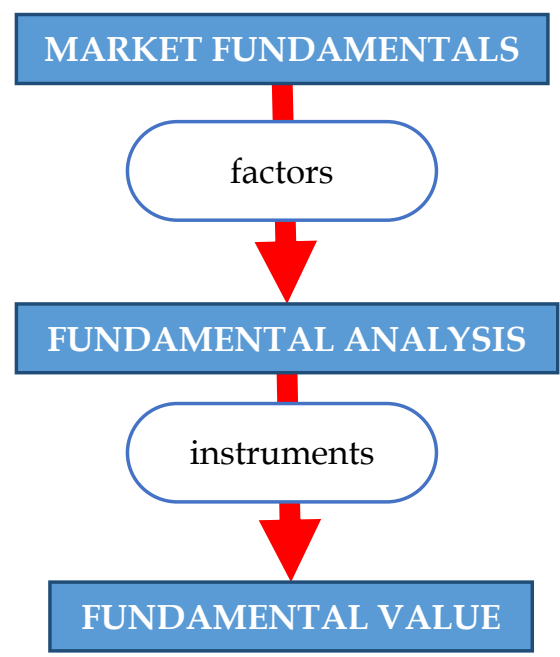

Fig. 1. Research areas of fundamental analysis. Source: own study.

\subsection{Fundamental Analysis on the Real Estate Market}

Fundamental analysis is comprehensively described for capital markets (equity or currency exchange markets). On the basis of this information, an attempt will be made to transfer and build on the existing principles in regards to the real estate market. This approach has been presented in the Fig. 2.

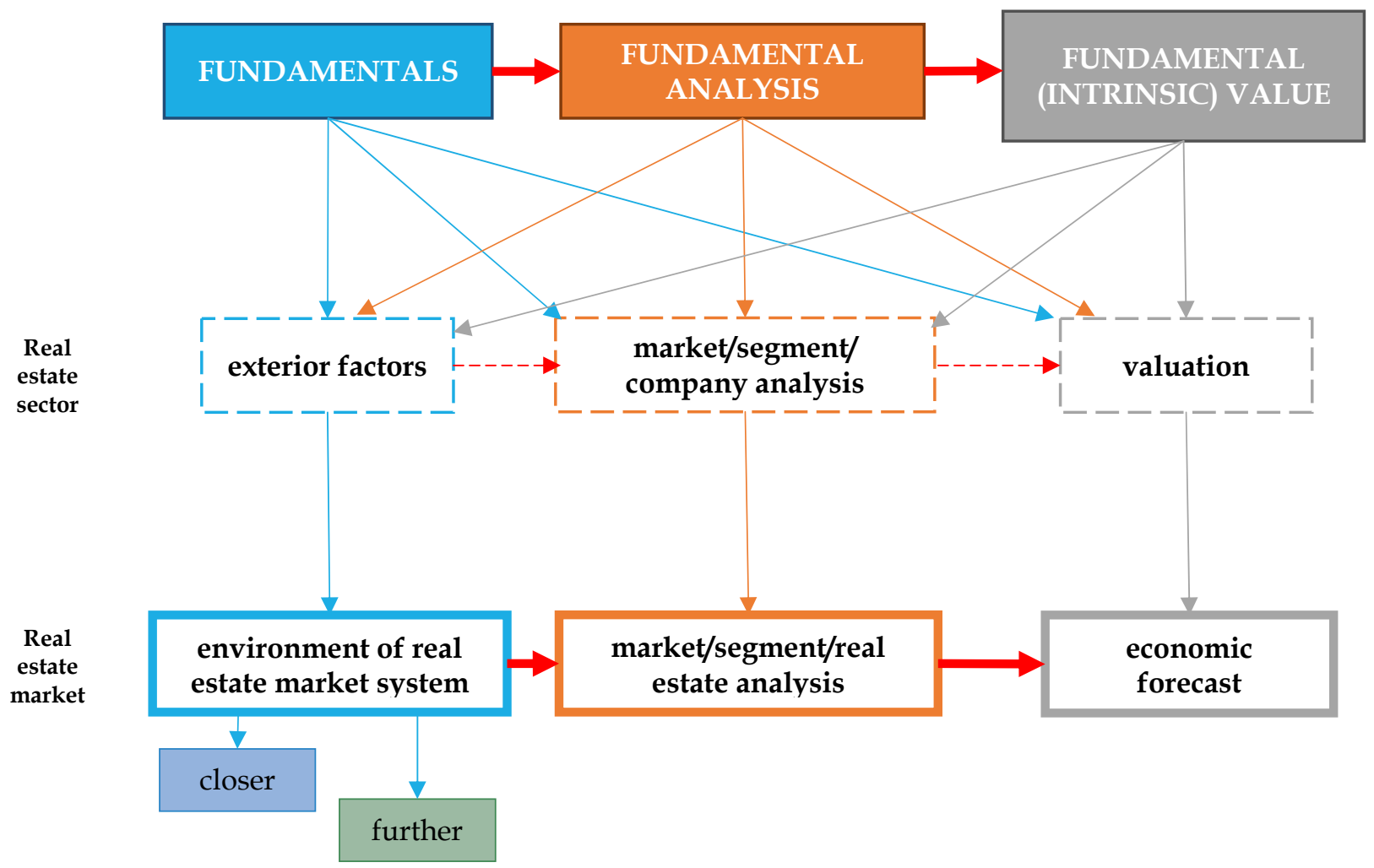

Fig. 2. Transfer of fundamental analysis from capital markets to the real estate market. Source: own study. 


\subsubsection{Fundamental Factors}

Obtaining correct results is mainly dependent on properly carrying out the first stage of fundamental analysis - the isolation of exterior factors influencing the forces of supply and demand, known as fundamental factors.

They do not determine the temporary behaviors of these two elements of the market mechanism, however, their role in longer periods is dominant. The company's condition and, therefore, its fundamental value, do not change drastically (KRZYWDA 2010, p. 57). Despite the substantial impact of fundamental factors on valuation, they are most frequently difficult to measure in the language of mathematics or by econometric models (BOROWSKI 2014, p. 10). Their influence on the value or price of real estates has been presented in the Fig. 3 .

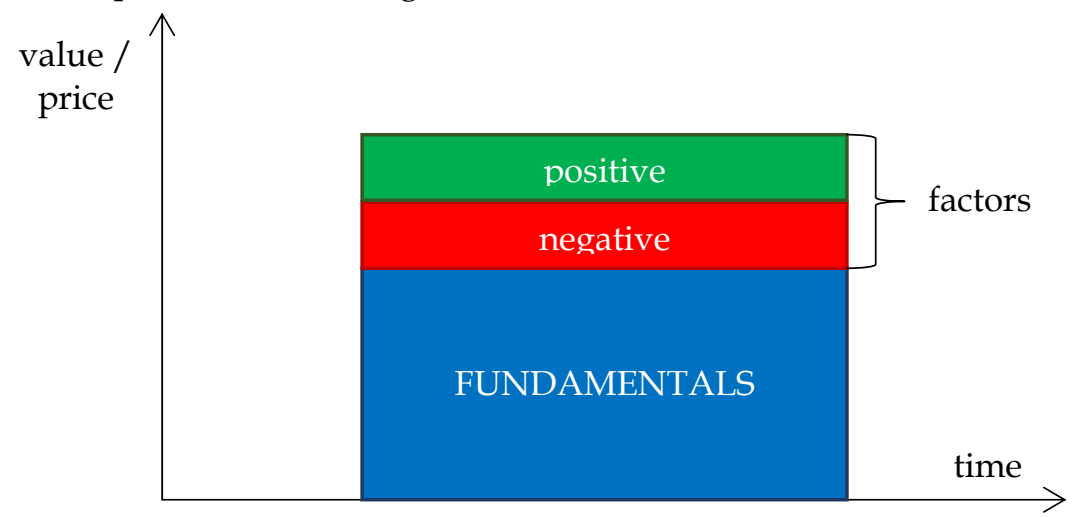

Fig. 3. Influence of fundamental factors on real estate value/price. Source: own study.

Exterior factors, considered in points or sectors, can be divided into the following groups (Fig. 4.):

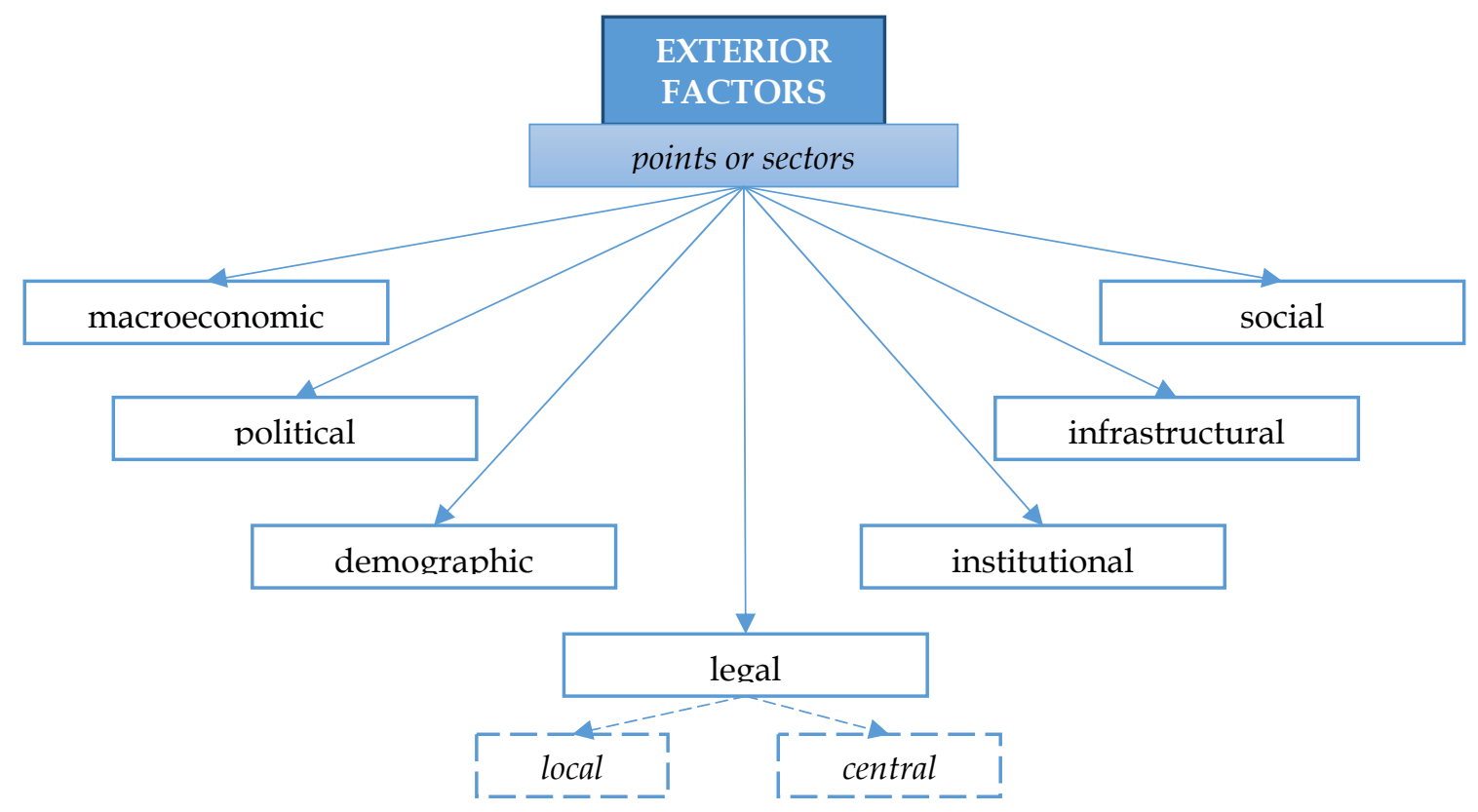

Fig. 4. Types of fundamental factors on the real estate market. Source: own study.

The following can be considered as exemplary fundamental factors on the real estate market (ŁASZEK, et al. 2009, p. 42):

1. on the demand side:

- degree of urbanization,

- external and internal migrations,

- number of households,

- incomes of the society,

- unemployment rate,

- credit availability, 
- interest rates,

- prices of substitute goods (costs of renting vs. buying),

2. on the supply side:

- administrative barriers prolonging the process of obtaining a construction permit,

- accessibility of building areas with full amenities,

- spatial planning system,

- quality of taxation instruments,

- housing and building policies,

- costs of construction and installation,

- competition between domestic and foreign markets.

Aside from finding and defining suitable fundamental factors, another problem that is likely to occur while conducting this phase of the analyses is assigning adequate weights to particular factors, depending on their influence on the fundamentals, including both on the real estate and capital markets (PANFIL, SZABLEWSKI 2013, p. 133).

\subsubsection{Fundamental Analysis}

The next phase of the research is the actual fundamental analysis of a selected sector/group/real estate. The course of the entire process, realized according to the "top-down" rule, can be reduced to the following steps:

1. macroeconomic analysis of the environment - determination of factors positively or negatively influencing the development of the economy in the country where the analyzed real estate is located,

2. sector analysis - examination of a group of similar sectors/real estates by analyzing qualitative factors characterizing a particular sector which create an additional opportunity for development,

3. analysis of a real estate's general condition- familiarization with all of the available information about a real estate to rate it in comparison with the whole sector, taking into account mainly non-financial aspects and performing a SWOT analysis, which evaluates the strengths and weaknesses of the real estate, along with opportunities and threats arising from the environment it exists in,

4. financial analysis of the real estate - rating the overall operation of a real estate and its life-cycle on the basis of suitable indices intentionally designed for this purpose, prepared from data available for the real estate.

Every phase of this analysis requires the analyzed real estate to be considered from three points of view: subjective (market participants), objective (market/segment/real estate) and systemic (relations between interconnected elements).

Only a comprehensive analysis of the information described above on all three levels can ensure obtaining proper results and drawing correct conclusions, and, most importantly, the objective appraisal of a chosen real estate's fundamental value.

\subsubsection{Fundamental Value}

Every appraisal, as the effect of subjective assumptions made by its authors, can never be considered as completely precise. Nevertheless, fundamental analysis aims to achieve maximal objectification of such valuation results. Its ultimate goal is the appraisal of so-called intrinsic value (termed "fundamental value" by the authors of the article when referring to real estate), meaning a true (objective, fair) value of the appraised object, uninfluenced by demand and supply, as opposed to the market value (being a consequence of market imperfection).

In literature, a definition according to which the fundamental value of a real estate is "a combination of the physical fabric of the building, environmental amenities, location, public services, marketing image, occupancy rate, and the availability of financing" can be found (BIBISH, KEENAN 2005, p. 47). Another source, on the other hand, states that it is a sum of discounted future rents, equal to actual rents or rents averaged by the market (HOTT, MONNIN 2008, p. 429).

In the case of investment decision-making, fundamental value is compared to the price of a real estate. Real estate with prices lower than the intrinsic value (undervalued $U$ ) should be bought, 
and those with higher prices (overvalued $O$ ) should be sold. The relationship between fundamental value and market price has been presented in Fig. 5.

Similarly to real estate valuation, choosing the method of a venture's appraisal is also mainly dependent on the purpose for which it is being carried out. However, as far as estimating a company's value, the best option appears to be the income method (PANFIL, SZABLEWSKI 2013, p. 120), whereas, in case of real estate, there are no suitable procedures of fundamental value appraisal as of yet.

The estimated fundamental value of a real estate entails a wide range of applications. Apart from economic forecasting or use in the analytical sector (ratings), as a maximally objective value, it would fit perfectly into diverse administrative tasks, being an excellent basis for charging all kinds of taxes related to real estate. What is more, fundamental analysis can be applicable in the case of objects for which a secondary market does not exist or which are not the subject of market trade (PANFIL, SZABLEWSKI 2011, p. 108).

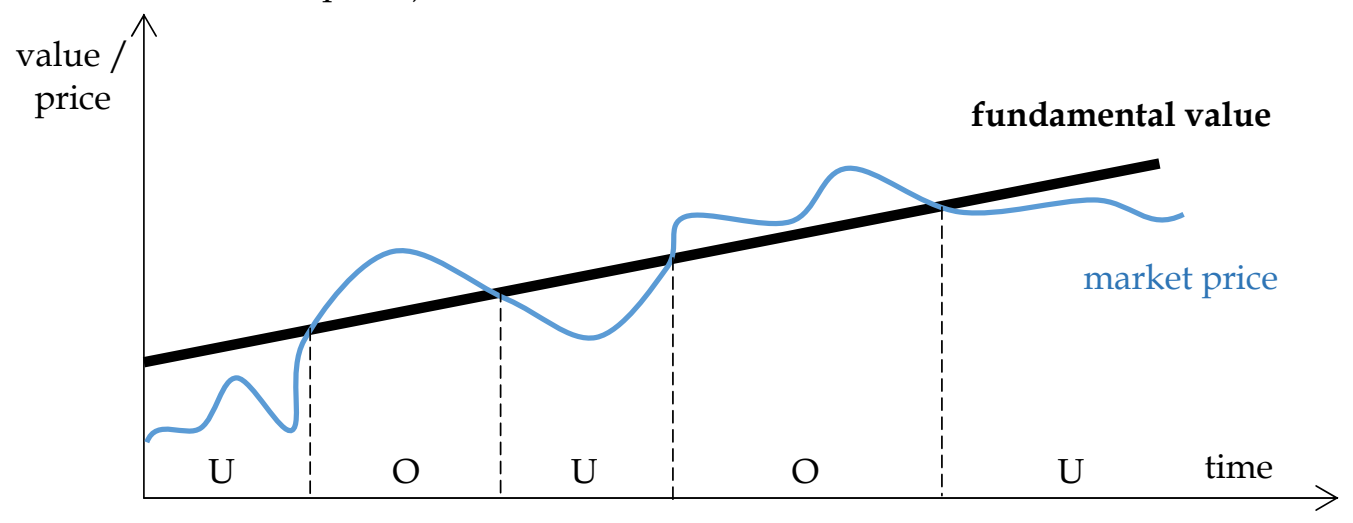

Fig. 5. Fundamental value of real estate versus its market price. Source: own study.

\section{Discussion and Conclusions}

On the basis of above-mentioned information, the following conclusions can be formulated:

1. Fundamental analysis is an analytical method with considerable development potential. The fundamental approach, along with behavioral and random factors, will enable a full understanding of the real estate market and the mechanisms controlling it.

2. The application of this analysis on the real estate market, however, requires the formulation of suitable standards for determining fundamental factors and assigning weights to them, formulating and calculating economic and financial indices, as well as methods and instruments of fundamental value appraisal. This can be achieved by basing off of existing principles referring to companies as well as a thorough observation of local and regional real estate markets in a longer period of time.

3. Issues related to this field and capability of its application on real estate market will comprise the main subject-matter of the research conducted by authors of the article in the future.

\section{References}

ARNOLD G., 2010, Inwestowanie w wartość. Jak zostać skutecznym inwestorem (Value Investing. How to Become a Disciplined Investor), Wydawnictwa Profesjonalne PWN, Warszawa.

ARnold G., 2010, The Financial Times Guide to Investing. The Definitive Companion to Investment and the Financial Markets. Second Edition, Pearson UK, London.

BiBISH J. E., KeENAN J. M., 2005, Real Estate Market Fundamentals in South Florida, Wharton Real Estate Review, Vol. 9, No. 2, pp.: 44-49.

BONENKAMP U., HOMBURG C., KEMPF A., 2011, Fundamental Information in Technical Trading Strategies, Journal of Business Finance \& Accounting, Vol. 38, No. 7-8, pp.: 842-860.

BOROWSKI K., 2014, Analiza fundamentalna. Metody wyceny przedsiębiorstwa (Fundamental Analysis. Company Valuation Methods), Difin SA, Warszawa.

CALANDRO J. Jr., 2009, Applied Value Investing. The Practical Applications of Benjamin Graham's and Warren Buffett's Valuation Principles to Acquisitions, Catastrophe Pricing, and Business Execution, McGraw-Hill, New York.

Cunningham L. A., 2001, How to Think like Benjamin Graham and Invest like Warren Buffett, McGrawHill, New York. 
Cunningham L. A., 2013, The Essays of Warren Buffett: Lessons for Corporate America, Carolina Academic Press, Durham.

DAMODARAN A., 2012, Investment Valuation: Tools and Techniques for Determining the Value of Any Asset, John Wiley \& Sons, Inc., New York.

DĘBSKI W., 2012, Rynek finansowy i jego mechanizmy: podstawy teorii i praktyki (Financial Market and its Mechanisms: The Basis of Theory and Practice) [in Polish], Wydawnictwo Naukowe PWN, Warszawa.

Edirisinghe N. C. P., ZHANG X., 2008, Portfolio Selection under DEA-Based Relative Financial Strength Indicators: Case of US Industries, Journal of the Operational Research Society, Vol. 59, No. 6, pp.: 842856.

FISHER P. A., 2015, Common Stocks and Uncommon Profits and Other Writings, John Wiley \& Sons, New York.

FunG S. Y. K., Su L. N., ZHU X. K., 2010, Price Divergence from Fundamental Value and the Value Relevance of Accounting Information, Contemporary Accounting Research, Vol. 27, no. 3, pp.: 829-854.

GAO Y., LI H., 2011, A Consolidated Model of Self-Fulfilling Expectations and Self-Destroying Expectations in Financial Markets, Journal of Economic Behavior \& Organization, Vol. 77, no. 3, pp.: 368-381.

GRAHAM B., BuffeTt W. E., ZWEIG J., 2003, The Intelligent Investor: The Definitive Book on Value Investing, Harper Collins, New York.

Graham B., DodD D., BuffetT W., 2009, Security Analysis (Sixth Edition), McGraw-Hill, New York.Gray G., CuASTIS P. J., WoOlRIDGE J. R., 2003, Streetsmart Guide to Valuing a Stock. The Savoy Investor's Key to Beating the Market, McGraw-Hill, New York.

HAFEZI R., SHAHRABI J., HADAVANDi E., 2015, A Bat-Neural Network Multi-Agent System (BNNMAS) for Stock Price Prediction: Case Study of DAX Stock Price, Applied Soft Computing, Vol. 29, pp.: 196-210.

Hagstrom R. G., 2009, The Warren Buffet Portfolio: Mastering the Power of the Focus Investment Strategy, John Wiley \& Sons, Inc., New York.

Hagstrom R. G., Miller B., FisHer K. L., 2014, The Warren Buffett Way: Investment Strategies of the World's Greatest Investor, John Wiley \& Sons, New York.

Hong K., Wu E., 2016, The Roles of Past Return and Firm Fundamentals in Driving US Stock Price Movements, International Review of Financial Analysis, Vol. 43, pp.: 62-75.

HotT C., Monnin P., 2008, Fundamental Real Estate Prices: An Empirical Estimation with International Data, Journal of Real Estate Finance and Economics, Vol. 36, No. 4, pp.: 427-450.

http:/ / bossa.pl/edukacja/AF/, available at 21.07.2015.

HU Y., LIU K., ZHANG X., SU L., NGAI E. W. T., LIU M., 2015, Application of Evolutionary Computation for Rule Discovery in Stock Algorithmic Trading: A Literature Review, Applied Soft Computing, Vol. 36, pp.: 534-551.

JAJUGA K., JAJUGA T., 2012, Inwestycje: instrumenty finansowe, aktywa niefinansowe, ryzyko finansowe, inżynieria finansowa (Investments: Financial Instruments, Non-Financial Assets, Financial Risk, Financial Engineering), Wydawnictwo Naukowe PWN, Warszawa.

KRZYWDA M., 2010, GPW II. Akcje i analiza fundamentalna w praktyce (Shares and Fundamental Analysis in Practice), Wydawnictwo Złote Myśli, Gliwice.

LAVIN A. M., ZORN T. S., 2001, Empirical Tests of the Fundamental-Value Hypothesis in Land Markets, Journal of Real Estate Finance and Economics, Vol. 22, No. 1, pp.: 99-116.

LyNCH P., RothCHILD J., 2000, One up on Wall Street: How to Use What You Already Know to Make Money in the Market, Simon and Schuster, New York.

LyNCH P., RothCHILD J., 2012, Learn to Earn: A Beginner's Guide to the Basics of Investing, Simon and Schuster, New York.

LYNCH P., 2012, Beating the Street, Simon and Schuster, New York.

ŁASZEK J., AUGUSTYNIAK H., WIDŁAK M., 2009, Euro a ryzyko bąbli na rynku nieruchomości mieszkaniowych (Euro and Risk of Bubbles on Residential Real Estate Market)), Narodowy Bank Polski, Departament Komunikacji Społecznej, Warszawa.

ŁUNIEWSKA M., 2008, Ekonometria finansowa: analiza rynku kapitałowego (Financial Econometry: Capital Market Analysis), Wydawnictwo Naukowe PWN.

ŁUNIEWSKA M., TARCZYŃSKI W., 2006, Metody wielowymiarowej analizy porównawczej na rynku kapitałowym (Methods of Multidimensional Comparative Analysis on Capital Market), Wydawnictwo Naukowe PWN, Warszawa. 
MALINOWSKA U., 2012, Rola analizy fundamentalnej w warunkach kryzysu (Role of Fundamental Analysis in Conditions of Crisis), Acta Universitatis Lodziensis. Folia Oeconomica, No. 262, pp. 29-40.

MurPHY J. J., 1999, Technical Analysis of the Financial Markets. A Comprehensive Guide to Trading Methods and Applications, New York Institute of Finance, New York.

NAZAROWA J., 2014, Portfolio Structure Planning and Its Future Price Forecasting Model, 8th International Scientific Conference "Business and Management", pp. 290-291.

OstrowsKa E., 2007, Rynek kapitałowy: funkcjonowanie i metody oceny (Capital Market: Functioning and Appraisal Methods), Polskie Wydawnictwo Ekonomiczne, Warszawa.

PANFIL M., SZABLEWSKI A., 2011, Wycena przedsiębiorstwa: od teorii do praktyki (Valuation of a Company: From Theory to Practice), Wydawnictwo Poltext, Warszawa.

PANFIL M., SZABLEWSKI A., 2013, Dylematy wyceny przedsiębiorstwa (Dillemas of Company Valuation), Wydawnictwo Poltext, Warszawa.

POMYKALSKA B., POMYKALSKI P., 2008, Analiza finansowa przedsiębiorstwa (Financial Analysis of a Company), Wydawnictwo Naukowe PWN, Warszawa.

RITCHIE J. C., 1997, Analiza fundamentalna (Fundamental Analysis), WIG-Press, Warszawa.

SuRdel P., 2004, Forex - Analiza techniczna (Technical Analysis), Wydawnictwo Złote Myśli, Poznań.

YAN W., WOODARD R., SORNETTE D., 2014, Inferring Fundamental Value and Crash Nonlinearity from Bubble Calibration, Quantitative Finance, Vol. 14, No. 7, pp. 1273-1282.

YEH Y., SHU P., GUO R., 2008, Ownership Structure and IPO Valuation - Evidence from Taiwan, Financial Management, Vol. 37, No. 1, pp.: 141-161. 